\title{
Public welfare or sectarianism: a new challenge for planning
}

Dr. Shlomit Flint

Centre for Advanced Spatial Analysis (CASA), University College London (UCL)

90 Tottenham Court Road, London W1T 4TJ, UK, Tel: 02030161696

Emails flint.sh@gmail.com, shlomit.flint@ucl.ac.uk,

\section{Abstract:}

This article examines the weaknesses of liberal planning institutions when dealing with organised group action. The case under review, Kiryat-Ha'Yovel neighborhood in Jerusalem, was considered as secular for many years. In 2000, the neighborhood became attractive to the nearby Haredi (ultra-orthodox Jews) group of the "Kol-Torah" community. Differences in life-style led to a collision between the group of "Kol-Torah", who began Haredification processes to change character of the area, and the veteran population, who tried to prevent it. Identifying the main engines of organised neighbourhood change and evaluating the difficulties of liberalism dealing with nonautonomous individuals in the housing market sheds light on similar processes occurring in other city centres with diverse population groups.

Key words:

Interest group

Group action

Planning

Haredi

Jerusalem

Territory

Boundaries, Borders

\section{Introduction}

Urban planning developed during the twentieth century under conditions of strong national welfare states, with a relatively weak civil society (Davies, 2001). The need to protect the public interest and guarantee its rights led to the establishment of a hierarchical system that intervenes in local planning policy throughout the developed 
world. Influenced by distinct local culture and norms, the liberal mechanism was designed to guarantee equality in the allocation of resources and appropriate standard of infrastructure for the various sectors (Dean, 2011). According to Healey (1997), planning is a social process built up from the particular social relations of a place: "interrelation of planning practices with 'formal' government and with business and social life... made the planning is not just a response to problems, but has the potential actively to shape the ongoing flow of events and attitudes" (Ibid). In urban reality, the main key actors in the planning process - planners and politicians - had to cope with interest groups characterised by diverse institutional structures, access to resources, and holding inconsistent territorial interests (Taylor 1998). A particular challenge to the liberal planning system is posed by groups committed to non-liberal laws and concepts, such us the Haredi Jews in Israel.

Haredi (ultra-orthodox) Jews define themselves in terms of their commitment to Halacha, the collective body of Jewish religious law that shape both individual daily life and the public space (Friedman, 1991). Unifying forces that motivate the Haredim to congregate and carry out most of their interactions within their own group, combined with separatist forces that cause them to segregate themselves from their surrounding society, have led to self-imposed concentrations of the Haredim in enclaves around the world (Valins, 2003). Spatial congregation reflects Haredi communalism, which is characterised by mutual support and a complex system of social and consumer services unique to that community. For the group's members, belonging to the group's territory reduces conflicts arising from contact with the modern world, strengthens social exchanges, and encourages cultural partnership. As to the leadership, spatial dispersal has ramifications for management and preservation of the community. Territorial concentrations of sect members facilitates control of lives and allows the leadership to maintain social dominance within a defined area (Waterman \& Kosmin, 1988). In Israel, demographic, social, and economic features have increased the growing pressure of the Haredi population in urban space in recent decades. As a result, flat prices in the Haredi enclaves are significantly higher than those of similar flats among the general population, indicating the importance of living among 'friends' for the Haredim. This pressure on the enclaves has increased, creating processes of cultural and social introversion and territorial spread into non-Haredi areas (Shilhav, 1993).

Most researchers attribute these processes to a range of social, economic, and political factors and prefer 'soft' terms such as 'segregation', rather than explicit reference to fundamentalism in the urban space (Aran, Stadler, \& Ben-Ari, 2008). Therefore, along 
with the extensive research literature that deals with collective behaviour as a social phenomenon, there is a conspicuous dearth of research dealing with the effect of group action on territoriality and the re-shaping of neighbourhoods - evidence of the complexity and elusiveness of the subject (Granovetter, 1978). This paper's contention, rather, is that in order to examine these processes, one must refer to the social system that drives the local process and the set of values from which it draws its strength. Although the Haredi ideology and its evolution into the present collectivist structure is often portrayed as having fundamentalist features (Almond, Appleby \& Sivan, 1995), this paper will examine the collective features of the referred groups and its urban expression in Jerusalem.

Since the establishment of Israel in 1948, it has been subject to fundamental conflicts, with Jerusalem at its epicenter. Other than the regional geopolitical conflict, the city is sacred to the three main monotheistic religions, thus inviting inevitable global tensions. The city has been associated with the primary social clashes in Israeli society, between Israeli Jews and Palestinian Arabs (Sharkansky, 1996), between Sephardim (Jews from neighboring Arab countries) and Ashkenazim (Jews of European origin) and between Haredi and secular Jews. Jerusalem is populated by 801,000 residents, of which $62 \%$ are Jews, Muslims comprise 35\%, Christians around $2 \%$ and $1 \%$ not classified by religion. The Jewish residents are overwhelmingly religious, with only $21 \%$ secular. The "Haredification" of Jerusalem [process whereby non-Haredim populations are replaced by Haredim] can be linked to every aspect of life and decision making in the city (Hasson, 1996).

The urban planning in West Jerusalem preserved the liberal trend of the first few years following the founding of the state of Israel, to unite various population groups for the creation of a common Israeli culture (ibid, 1996). According to this view, the Haredi community had not been considered as a singular one which required a special urban space, but instead as part of the wider Israeli melting pot. Consequently, the Haredi territory has been restricted by land uses which contradict its nature and every contact bears the seeds of a territorial struggle with neighboring populations over living space (Shilhav \& Friedman, 1985). High population density and increased prices for apartments in Haredim enclaves has motivated a constant migration of population from the Haredim enclaves. "Haredified" neighborhoods have two key characteristics: proximity to an existing Haredi congregation; and a location close to inner-city neighbourhoods (Hasson, 1996). Influx of Haredim into secular neighbourhoods has caused friction and bitter struggles over the city's character. 
The Kiryat-Ha'Yovel neighborhood of Jerusalem is an interesting case study which can be used to examine important elements in the ability of a cohesive community to harness private interests in order to wrest control of space from other groups, thereby creating a 'contiguous' Haredi living space. This paper examines how interest groups holding different values adopt strategies to claim territory, identified the relationship between the individual and his/her group, while also considering the role of liberal planning in the conflict.

\section{Theoretical background}

People, the actors in the urban space, shape the built environment in ways that reflect their lifestyle, culture and values. Urban structure results from various levels of cooperation emerging between relatively free individuals (Wirth, 1956). Indirect cooperation reflects similarities in the way people 'read' and interpret urban space, and direct cooperation reflects economic interests and social organisation (Fischer, 1982). In recent decades, with the dissolution of the social, economic, and political frameworks that constitute the background for planning, the impact and the pressure of direct cooperation of interest groups on urban space has considerably increased (Alexander, 2002; Kolossov, 2005). The difficulties of liberal planning to implement its agenda and regulate resources between groups and individuals will be discussed in this paper: In order to explain the way individuals incline towards and cooperate with groups, including local resident associations that motivate residential dynamics and actions, the research will use the themes of interest groups and Group behaviour in the urban space. The theme of territoriality and re-shaping neighborhoods will elaborate the way different groups adopts different strategies to claim space.

'Interests' are defined as motivations for action which affect social behaviour, judgment and choices, and the aim of an 'interest group' is to influence public opinion and/or policy (Miller 1999). Interest groups vary in size and institutional structure, their organisation, access to authorities, motives and sources of funding; some have wide ranging long term social purposes, others are focused and are a response to an immediate issue or concern. Some are supported by powerful businesses or political interests and exert considerable influence on the political process, others have few such resources (Stone \& Salisbury, 1969; Denzau \& Munger 1986; Hendricks 2006). In the classification of interest groups, it is common to distinguish between public-interest, which is conceived as a value commitment to benefit the whole public, and private-interest, which represents the values of western individualistic culture and can be assigned also to 
groups and collectives (Funk 2000). Likewise, although the institutional structure of the groups, their organisation, access to authorities and sources of funding allows us to categorise them according to their type of interest group (Drezon-Tepler, 1990), these terms are also not absolute. Hence, the research will examine how interest groups characterised by different levels of cooperation between the individual and his group, affects the residential structure.

The effect of cooperation between a city's free individuals on its urban structure was considered, for example, by the Chicago School at the beginning of the 20th century. According to their "invasion-succession" theory (Park, 1936) and its more updated explanation (Hawley, 1950), spatial competition between groups is an ecological process which enables us to describe collective behavior. In the absence of clear behavioral norms, spontaneous social gathering is the means to improve an individual's ability to cope with the challenges of urban life. As these mechanisms are influenced by living costs, areas with different resources specialise in ways which give them a competitive advantage over other regions (Blumer, 1951). Over time, the original population leave and the area changes.

As opposed to indirect collaboration, collectivist behavior, which is driven by a clear leadership in a given place and time, is defined as group behavior (Saegert \& Winkel, 1990). Authority reaches consensus, defines rules and creates an organised segregated pattern (Anderson \& O'Dowd, 1999). This behaviour, characterising organised groups as Group purchasing organisation and Gated Communities, is relevant to explain business practice like racial blockbusting in American cities during the 60's and 70's (Mehlhorn, 1998), and is particularly strong among traditional communities (Bankston \& Zhou, 1995). Many of these communities attempt to revive old traditional lifestyles by using modern fundamentalist mechanisms that reinforce a compliance due to identification different from compliance out of fear or under explicit threat. Both individuals who choose to be accepted into the group as well as individuals who born into it develop their identity under social pressure (Castells, 1997), usually around a charismatic leader who translates concepts and ideas from the scriptures into practical behaviours. An individual's needs become congruent with the group's interests, and the individual's welfare aspect is judged by his status within the group and his contribution to the community (Ammerman, 1987). As part of the community, individuals are expected to concede their free will and to subordinate their interests to those of the group, even in cases where they are indifferent or even harmed by them (Tajfel \& Turner, 1986). 
At times the asymmetrical balance of power between neighboring communities creates group violence (Boal, 2008). When the group members realize they are more likely to achieve their goal when acting coordinately and simultaneously, they may consolidate under a well-defined authority and use their enclave as a base for group action. In this behaviour, previously described in conflictual cities, such as Belfast, Nicosia or Sarajevo, the authority will use its access to capital - whether financial or knowledge based - to claim the territory for themselves and expand it by forcing out everybody they deem not belonging (Gottman, 1973; Malmberg, 1980; Sack, 1983). Thus, long-term structural and symbolic acts of group violence against a religious minority in Ahmedabad transformed mixed Hindu and Muslim working-class neighborhoods into a patchwork of monoreligious localities, with the meeting points between these areas referred to as "borders" (Desai, 2007). Whether these borders are gateways or barriers, weak or strong (Paasi, 1996; Donnan 2006: 2), rigid or flexible, highly populated or virtually empty (Altvater, 1998, Newman, 2003), or even gray spaces tolerated quietly (Yiftachel, 2006), they display differences of inequality and asymmetry, whether economic, political, cultural or social between communities (Giddens, 1984:17, 85).

In the liberal ideology it is only in benighted, backward or pre-modern societies that individuals put an unchosen group identity - such as membership of an ethnic group or nation - ahead of their interests as individuals. Thus, spatial pattern of ghettoisation, segregation and sectarianism that obscure the fundamental interests which humans have in common, is considered as outsiders to the civilized liberal world (Ignatieff 1993). Planning, in this respect, think in terms of individuals rather than collectivities and seek for erosion of ethnic solidarities and weaken the boundaries between groups. Healey (1997: 87) explained that "Planning practice is not an innocent, value-neutral activity. It is deeply political. It carries value and expresses power. The power lies in the formal allocation of rights and responsibilities, in the politics of influence, the practices through which 'bias' is mobilised, and in the taken-for-granted assumptions embedded in cultural practices". Recently, with the growing impact of interest groups on urban space, the assumption of liberal planning that democratic institutions, including the market, will 'balance' competing interests in accordance with local needs, has been weakened (Bollens 2000; Alfasi, 2014). In the "vibrant" city of Jerusalem, the tolerance of systems towards individuals from the private investors and strong interest groups - mainly religious groups - involved in planning increased, as well as the temptation for corruption. This process emphasised the difficulties of the individualistic orientated institutions to deal with the residential behaviour of groups. 
Jerusalem planning lies on the seam between charting national policy and the pressures of diversified urban politics, subjected to the regulatory and hierarchy system of Israeli planning. Guidelines go from top to bottom, from the national-level institutions through one of six districts - one of them is the Jerusalem District Planning and Building Committee - to the local Planning and Building Committees. Main liberal aspects of this system is the large number of representative bodies in the committees, which include professional representatives of government agencies, municipal authority, environmental and the general public; and public participatory that enables the public to bring applications to both already created and new plans (Alterman \& Gavrieli, 2008). The range of views represented in this system reveals a conflict between two normative systems, secular and religious, which from the perspective of both of them, behaviour according to the second system leads to a law violation. Contrary to secular politicians' pragmatic views, where the rule of law exists and is binding but can be taken lightly when it is required by political logic (Sprinzak, 1986; Malkin, 2005), scripture and its interpretations are also a source of social, economic, and political authority, which sometimes increasesd the willingness of Haredim decision-makers to divert public resources to the sector they represent (Shilhav, 1998;127).

\section{Methodology}

The Haredim are reluctant to disclose information that enables authorities and researchers to estimate the size of the population. Attempts to gather statistical, demographic, or any other information, are impeded because they are not considered as an independent category, so quantitative data referring to the population is likely to be based on estimate, assessment, or survey.

This study is based on "real data", provided anonymously by the people themselves in 2009 at the level of single apartment, section, and building. First, all 653 buildings in Kiryat-Ha'Yovel were surveyed. In each building/section, representatives of the building committee or the long-standing residents were asked about the identity of the residents of the building, and whether they rented or owned their apartment. From the data collected in this manner, a map of the population distribution was created, from which a secondary map was derived for each discrete population group. The population distribution of the Haredi-Lithuanians was particularly marked because it was prominently congregated in the large residential buildings on Zangwill Street. In consequence, the dynamics of residence on the street was then examined at the 
individual apartment level. Overall, Zangwill Street contains 347 apartments in nine residential buildings with 46 separate entrances.

Secondly, although co-operation was limited, most of the new residents indicated that they belonged to the Haredi-Lithuanian community of Kol-Torah, based in the adjoining neighborhood of Bayit-Ve'Gan, and gave date of entry into the new apartment.

To reconstruct the dynamics of population replacement, 246 veteran residents - who sold their apartments between 2002-2010 - were identified and interviewed about the sale process. They provided information about the price and the month/year of the sale. In addition, they were asked about the approximate number of secular families still residing in the building at the moment of a sale. Ex-owners were willing to reply to these questions in $76 \%$ of the cases, and cross-checks with data supplied by real estate agencies increased the percentage of cases for which the price and the number of secular tenants are both available to $88 \%$. The market price of an apartment at the moment of the sale was estimated based on cross-referenced data provided by three Kiryat-Ha'Yovel main realtors. They produced information on the population exchange and expressed the dynamic processes, making it possible to estimate residential markets in the neighborhood.

The characteristics of all apartments and households were organised as a highresolution layer, in which every record is related to its corresponding building. The layer was then integrated into the area GIS provided by Jerusalem Municipality. Additional layers pertain to topography, roads, land parcels and buildings, updated to 2004. This spatial-temporal GIS facilitated investigation of the residential micro-dynamics of Zangwill Street while referring to residents' identities and turnover of apartments and spotlighting the group organisation and the leadership rule behind these processes.

In addition, 30 interviews were conducted with key figures from various fields. Those involved with the Kol-Torah community were interviewed about spatial relations between the individual and the community, and the economic aspect of the yeshiva in regard to housing. Functionaries in Jerusalem Municipality were interviewed regarding the capabilities and limitations of the planning system in the encounter between population groups. Residents from various population groups and members of the secular "Action Committee to Preserve the Character of Kiryat-Ha'Yovel" were interviewed about activities in the public and private space. The information was cross-checked with blogs, articles, and Haredi internet sites, which offered a range of different types of knowledge and perspectives on their communities. Observing these conflicts in Kiryat-Ha'Yovel will enable us to explain the idea of "Terrain of interests". 


\section{The Haredi in Jerusalem}

The Haredi population is distinguished by internal, nuanced distinctions among its subsects, expressed in different values and normative behavior. Common to all is the great importance given to their holy studies, which is expressed in an individual's social status: a "scholar" who invests and succeeds in his holy studies gains a high social status (Gonen, 2006). This phenomenon prevails mainly in the Israeli-Lithuanian Haredi community and reinforces an individual's solidarity with the community's values, limiting their economic development (Friedman, 1991). However, despite the economic status of most of the individual members tending to be very low, the economic power of the Haredi community as a whole is considerable: many communities maintain financial resources and services composed of donations and taxpayer money through state support for religious institutions (Hasson, 1996).

The increase of the strength of the Haredi communities has become highly important when socio-economic issues, such as marrying young and high fertility rates - some $6 \%$ annually - (Berman and Klinov, 1997) exacerbate the growing pressure of the Haredi population on urban space. The solution proposed by the State of Israel is to allocate land for constructing Haredi neighborhoods. This development, which began in the 1960s, accelerated in the 1980s with the construction of new neighborhoods and cities to accommodate Haredi populations unable to solve their housing problems in the free market (Gonen, 2006). However, despite the state's involvement, official solutions were inadequate for meeting the demand. As a result, Haredi pressure on the enclaves increased, creating processes of cultural and social introversion and territorial spread accompanied by the exclusion of the existing local population (Feitelson, 2011). Shilhav (1998: 127) explains that the strength of the Haredim in national and local politics has increased the willingness of Haredi decision-makers to cultivate Haredi social-spatialcultural segregation: "Haredim adopt modes of operation and 'rules of the game' that are quasi-universal, but their real aims remain particularistic". Thus, local authorities often provide the necessary regulation for maintaining the Haredi public space; including setting Eruv wires; a ritual enclosure to make the area a 'private domain' (a concept in Jewish law which makes it permissible to carry objects on the Sabbath), closing streets for traffic on Saturdays and allocating buildings for religious services.

In the Haredi society, the Israeli-Lithuanians are considered a religious elite, and thus set the norms for Haredi world (Gonen, 2006). The individual identities of IsraeliLithuanians are defined at all levels, classified by their rabbinical figures and yeshivas 
(higher education institutes), which are all subject to hierarchical leadership (Friedman, 1991). An individual's life is centered on the Yeshiva, an institution of higher religious studies that also provides social services, including children's education and basic welfare. The government provides stipends to the study institutions directly, but these funds are fully regulated and distributed by the Rabbis exclusively: small living stipends are given to each Torah student family (Gonen, 2006). The community's leaders regulate a system of control and supervision, creating dependency of the individual on his community. Nowadays, when housing enhancers and young families have difficulties realising their preferences to live within their own community, the importance of group behaviour has increased. This is particularly relevant to the Israeli-Lithuanian Haredi community of Kol-Torah, interested in creating territorial continuity in Kiryat-Ha'Yovel neighbourhood in Jerusalem.

\section{The case study: Kiryat-Ha' Yovel}

In 2009, the population of Kiryat-Ha'Yovel, in south-west Jerusalem (Fig. 1), comprised about 17,500, inhabiting 653 residential buildings with 6428 apartments (Picture 1). Originally, most of the apartments in the street were about the same size - 48-55 sq. $\mathrm{m}$. (2.5 rooms), though some of them were enlarged. The neighbourhood was populated by a secular population, along with National-Religious and Haredi populations, including members of the Sephardic sects, the Chabad-Hassidic community, and Lithuanian subsects classified by national origin: Israeli, American, French and Sephardi-Lithuanian (Table 1). Each sub-sect has its own community institutions and generally did not marry outside its own group.

[Place Figure 1 about here]

[Place Picture 1 about here]

[Place Table 1 about here]

In recent years, Israeli-Lithuanians of Kol-Torah have been purchasing apartments on Zangwill Street, the northeastern boundary of Kiryat-Ha'Yovel (Fig. 2). This Yeshiva was founded in 1939 by German immigrants who arrived in Israel following the 'Kristallnacht' pogrom, and although its scholarly trend was not initially a militant ultra-orthodox, it changed over the years. Today Kol-Torah is considered one of the most important yeshivas of the Torah world, and the secular and the national-religious residents of 
Kiryat-Ha'Yovel are concerned about its impact on the public spaces, and its possible ramifications.

[Place Figure 2 about here]

\section{“Terrain of interests" between Haredi and secular in Kiryat-Ha'Yovel}

Interests between the individual and his group

The Haredi community of Kol-Torah

In recent years, demographic, social, and economic pressures have limited involvement of the leadership in the community's daily life, and its ability to enforce group discipline for continued residence within the community has been weakened. By default, the leftovers are driven to establish residence far from the original group enclave. The geographic isolation that is created between the generations threatens the continuity of the community: on the one hand, the population living in the original enclave is aging, and on the other, the lifestyle in the new communities tends to adapt itself to the new conditions of life (Shilhav, 1993). Interviews with key figures in the community, such as Ben-Porat, Y., a local politician (Feb. 26, 2010), Carmel, M., Head of Degel-Hatorah building association (March 1, 2010) and Itzkovitz, S., an advertising promoter of the Lithuanian group (March 1, 2010), revealed that these processes which were a source of concern for the leaders of the "Kol- Torah" community from the Bayit-Va'Gan neighbourhood, motivated Rabbis Elyashiv and Auerbach to encourage group action to expand the original living space of the group.

An individual's identification with their community and their desire to raise their children in a homogeneous religious environment evokes conscious ideological and moral recruitment. Clear-cut monitory mechanisms ensure compliant behaviour, allowing the leadership to impose discipline and organise matters in accordance with its preferences. The expressive incentive for the group's members is that they would help out in the process of trying to obtain the group's goals. Libskind B., director of Kol-Torah yeshivas 1987-2011, asserts: "When the students cooperated, we were able to build new educational departments, attract new pupils, and enlarge the community's area. That way we all benefited" (October 17, 2011). The private-interest group of Kol-Torah is characterised by a well-coordinated institutional structure, organized funding and members' strong commitment, which enabled them to mobilise dedicated manpower and significant resources to realize the community's segregated preferences.

\section{The non-Haredi population of Kiryat-Ha'Yovel}

- The individuals' population of Zangwill Street 
The mixed population comprised of individuals with diverse beliefs and interests. Most of them were secular Jews, mainly autonomous homeowners. Confronting the new incomers, who were backed by capital and group support, the veteran residents had no community support.

The direct cooperation of the Haredim with their community created pressure on the residents, who were exposed to limitations such as restrictions on traffic on the Sabbath and holidays. This aroused anger and infringes upon the secular lifestyle. Avi Nai'm, a former resident, explains: "Their entry into our street means that we cannot go on living as we used to. All of our rights were trampled. They commented about our clothes, sprayed clothes hanging on the clotheslines, threw rocks when we drove on the Sabbath, hung signs in the building about "Passage only in modest dress"; advertisements with women's faces were vandalized". Ultimately, most of the veteran residents preferred to sell their apartments to the Haredim and leave, causing a fall in prices and an accelerated re-population.

\section{- The "Action Committee to Preserve the Character of Kiryat-Ha'Yovel"}

Organized secular efforts began in August 2008, when haredification was at its height.

Activities for establishing a cluster of Haredi kindergartens on a lot originally designated as the site for establishing a memorial for fallen soldiers from the neighborhood violated the Secular-Haredi status quo. These acts, carried out with no building permit at the instruction of Deputy-Mayor Pollak, outraged many of the secular residents. Some secular residents then decided to establish a voluntary group - the 'Action Committee to Preserve the Character of Kiryat-Ha'Yovel'. Gilboa R., one of the main activists, claimed "Beyond our concern about the threat to the character of the neighborhood, members of the committee expressed the disappointment of the non-Haredi residents of Jerusalem who were seeing entire neighborhoods, like Ramat-Eshkol and Ma'alot-Daphna in northern Jerusalem, become Haredi. Apart from the sense of urgency and the desire to protect our homes from haredification, was the sense of being abandoned by the city authorities" (March 24, 2010). This fed the spirit of opposition and powered the initiative to turn Kiryat-Ha'Yovel into a symbol of blocking the process (Nahum-Halevi, 2009).

As an instant and random interest group, whose members regarded themselves as independent actors free to pursue individual interests, the secular residents were united in their aspiration to the right to freedom of expression - to travel and/or conduct consumer and cultural activities on the Sabbath and Jewish holidays. In counterbalance, their demands that the authorities defend "their rights" and stop sectarian allocations of public resources produced debate over their real dedication to mixed neighborhoods. Lack of consensus about values, modes of action, leadership and vested interests 
together with poor organisation and coordination deterred many people from acting. Apart from some 15-20 central figures, mainly white-collar citizens, most registered members only acted on a short-term basis or in a specific project.

\section{Organisation in housing}

\section{The effects of Group Action of "Kol-Torah" Community}

- The emergence of an internal housing market in Zangwill Street

In order to understand how group action works, this research examined the rapid occupation of Zangwill Street by Kol-Torah Israeli-Lithuanians between 2002 and 2009 (Fig. 3). The rapid process indicates the abilities of an organised community when it competes with non-organized individuals. The first step was critical for the success of the haredification. Figure 4 illustrates the two stages in the group's penetration:

1. Lone pioneers identify apartments for sale and enter them gradually (20022004).

2. Massive penetration turns a 'non-hostile' into 'friendly' area (2005-2007). The rapid movement patterns were well-planned. The designated area was marked by the leaders of the community. In 2002, three Lithuanian families purchased apartments in different housing projects. By 2004 a few Lithuanian families were living in Zangwill Street. Pre-planning was evident in the acquisition of apartments in the same cluster of buildings (but not in the same section).

[Place Figure 3 about here]

[Place Figure 4 about here]

Data obtained from local estate agents (Bunin, E. May 14, 2009; David, A. May 11, 2009; Stern, S. May 14, 2009; Sternberg, C. May 17, 2009) and former residents enabled reconstruction of the gradient of prices and an examination of the market dynamic as of 2002 :

1. Penetration: two apartments purchased by Lithuanians above market price.

2. Before "tie-break": apartments 3 and 4 purchased below market price.

3. Emergence of an internal-market: Zangwill Street becomes identified with IsraeliLithuanian population. Apartments switch hands rapidly, from secular population to Israeli-Lithuanian. Prices inside the community territory rise again, creating a property line around/within its boundaries. According to realtors, the community organisation provided financial support to the Kol-Torah "spearhead". The first secular residents to sell their apartments received approximately $20 \%$ more than the market price. 
Until 2005 , some $35 \%$ of the purchased apartments were randomly distributed between the buildings. As the number of Kol-Torah inhabitants increased, prices declined and even fell below market level, but when the street became more popularly accepted, prices rose again (Fig. 5).

\section{[Place Figure 5 about here]}

The realtor Shlomo Stern described how processes within the Kol-Torah community affected prices: "When an area is designated as Lithuanian, demand increases. People fear that apartments will be 'snapped up', and that they will lose the opportunity to live among friends, so that they must wait for another area to be "koshered", perhaps farther away. This causes housing prices to rise. The market which drives the price rise here is not secular or mixed, but within the Lithuanian community itself. So ultimately the buyer is the one who receives more from the community's funds".

As of 2006, Haredi direct collaborations has succeeded in strengthening the Haredim presence on Zangwill Street. Group actions motivated by ideological practices expanded the group's territory while segregating the group from other Haredim and the veteran population of the neighborhood, creating a homogeneous housing pattern. Today, the Kol-Torah community has succeeded in wresting control of Zangwill Street and almost all the 347 families belong to the community. Single apartments that still belong to secular residents are either publicly owned or business locations (i.e. a dental clinic). The borders' results from Kol-Torah's group action for expansion of the community territory are clear and defined, displaying asymmetry between communities: while the outsiders non-Haredi are varied and non-organized, the insiders Haredi are present in unified traditional garb in the public areas.

- From the spearhead of Zangwill Street to other parts of the neighborhood The entry of the Kol-Torah community into Zangwill Street has led to the entry of other Lithuanian-Haredi groups into the neighborhood. Cross-referenced data from residents, realtors, blogs and articles from Haredi websites indicate that apart from the Chabad community, members of the 'Pe'er Yakov', 'Hevron”, and 'Tiferet Yisrael' yeshivas infiltrated the neighborhood spontaneously, after and due to the organised IsraeliLithuanian invasion .

Goldberg, Y., a former Israeli-Lithuanian who lives in the neighborhood, explained: "This neighborhood has already undergone haredificaton. There are few secular people left. 
For Israeli-Lithuanians, it is totally Haredi" (10 March, 2010). Without communal funding, urban processes limit their ability to realise their preferences, and individual decisions are open to spatial competition in a free market. Each household is responsible for finding its place within the communal space. The non-organszed purchases have increased the presence of the Haredim groups throughout the area, yet could not guarantee a suitable environment for the individuals to fulfill their community obligations.

Examination of this situation in Behadrey Haredim, the Haredim news website, revealed some of the housing purchasers' considerations: "Based on what I know about the neighborhood, there are areas there that cost between $\$ 80000-\$ 100000$, but the question is which Haredim residents reside in that area?" Another browser answered : "I recommend that anyone looking for an apartment in Kiryat-Ha'Yovel, even if he is not Lithuanian, not be deterred... Place the educational consideration opposite the financial consideration. Will you be able to raise your children here in the next ten years"?. This correspondence reveals the doubts among the people who were purchasing apartments without any guarantee about the identity of their future neighbors. Thus, even when an area is specifically marked out, it is still the individual who must make the investment in the face of uncertainty regarding the future character of the area. Hence the areas which the Haredim have entered in a non-organised manner- mainly into housing complexes on Stern Street, and afterwards to the peripheral streets of the neighborhood, Hantke and Brazil, which have large residential buildings) Fig. 6) - tend to be more heterogeneous, populated by members of various communities and sects.

[Place Figure 6 about here]

\section{Attempts of the Action Committee to Provide Obstruction in Private and Public Spaces}

The action committee tried to convince secular residents, at personal financial sacrifice, to refrain from selling apartments to Haredim. Mandler, D., a main activist explained: "Committee members appealed personally to families advertising apartments for sale, and tried to dissuade them. However, many veteran residents acted individually, preferring to realize the economic value of their apartments" (May 18, 2009). This inability to influence individuals and to dissuade them from selling their apartments also limited the committee's influence on the public space.

The committee then focused on the image of a young, mixed neighborhood, and on persuading local authorities to enforce the building laws. In addition to the campaign against Eruv wires, the committee organized Friday night cultural activities, a 
demonstration, a clothing sale, Friday afternoon performances, and summer night film screenings, all of which emphasised the heterogeneous identity of the neighborhood and its struggle against haredification. The secular presence in the public space was intended to indirectly influence residents to refrain from selling their apartments to Haredim, and to present a united front to influence the municipal decision-makers. In practice, many secular individuals were unable to withstand the pressure of the organised group, as well as the fear of being a minority and the daily restrictions, and consequently were motivated to leave.

\section{Potential for influencing planning decision making}

\section{Kol-Torah: aim justifies the means}

Deep social and cultural roots as well as strong mutual interests motivated Kol-Torah to act in favour of influencing planning decisions, which they deployed for sectorial goals. In the past decade, there has been an increase in the number of Israeli-Lithuanians related to the Kol-Torah community in key positions on Jerusalem's City Counci, for instance Rabbi Lapolianski served as Mayor of Jerusalem (2003-2008), one of his deputies, Rabbi Maklev, held the Construction and Planning Portfolio since 1993, and another deputy, Rabbi Pollak, was chairman of the Construction and Planning Committee (20032008). In addition, the Deputy Mayor is currently Rabbi Pindrus. In the context neoliberal competitive economy lifestyle, as the number of the group's representatives and their influence on legislature increases, their ability to use rights to occupying space and claiming resources increases accordingly.

Barkat, the secular mayor of Jerusalem since 2008, explained that the allocation of public resources takes place according to the liberal premise: "We should match the public resources to the residents' needs to reduce friction between the various sectors in the city" (Shiloh, 2009). However, Bin-Noon A., head of the Municipality's public building division, explained the pressure of the group's representatives: "We were contacted by Elyashiv's people, but we cannot build any more at present, and there is no vacant facilities" (May 29, 2008). As public resources are limited, the uncompromising need of the Haredi sub-sect for segregated institutes - particularly synagogues and various educational institutions around which the community is concentrated - encourage activation in contravention of the planning permit.

Rabbi Elyashiv's instruction "Don't give in even if you break the law" (Katz, 2009) shows that in a possible clash between community duties and state law, the commitment to the community is higher. The group's members, thus, were encouraged to engage in local 
politics and even dissociate themselves from Torah in order to achieve their sectorial worldly goals, mainly achieved through construct in violation of a permit/without a permit and anomalous use/change of designation, such as the establishment of an Eruv, the destruction of non-Haredi bulletin boards / advertisements and the throwing of stones on the Shabbat day. T. Katz, head of the municipality`s Department of Licensing and Supervision, explained that although they were aware of the illegal activity taking place, they were powerless to enforce planning laws in the neighborhood: in a built-up area, it can be hard to detect zoning violations, and so in the inner city, the subject is neglected. If no one reports, the inspectors will not look for violations on their own initiative. They cannot know just by visiting an area if there is a violation, unless they crosscheck their data with the licensing department, and that is not their job. In any case, because of the overload, town planners only manage the urban aspects of civil society, and cases are closed due to a lack of public interest (May 29, 2008).

\section{The Action committee: Minimal achievements}

After a long period in which a member of the Lithuanian group was mayor of Jerusalem, the election was won by the secular candidate, and the Action committee hoped to enlist him on behalf of their interests: "We wanted the municipality to stop it. To refuse to establish sectorial institutions without permits, stop sectarian allocations, and promote projects to attract young secular people to the neighborhood" (Mandler, Jan 19, 2010). In practice, the election gave rise to a broad coalition of various sectors of the city's population, and the mayor's ability to influence local processes was limited.

The committee refused to accept the renunciation of the authorities from what they saw as their role. They demanded that planners intervene in the development of the neighbourhood and managed to raise public interest in the policy process. Gilboa explains: "We must guarantee that the public resources do not serve separatist groups. It is important to act at the level of the municipal decision makers and to bring about the closing of 20-30 illegal Haredim institutions operating in the neighborhood". In collaboration with the community council, the legal adviser to the municipality, and municipal planning institutions, the committee promoted legal action to prevent the unlawful allocation of public resources to the Haredim. Although their influence on planning was indirect, the main achievements of the veteran population was the initiation of an outline plan that provided a comprehensive planning framework for the neighborhood and the inclusion of issues of sectarian allocations and illegal activity on the public agenda. 
Despite their achievements, the unorganized group was unable to protect their cultural heritage, identity or living space from being taken over. The haredification process continues to occupy space, claim resources and affect lifestyle. Although the battle is also taking place at the level of the municipality, the office avoided issuing policy interventions in the conflict. Bin-Noon explains: "We have no full understanding and no ethical value to cope with conflicts between diverse population groups. We are powerless to enforce planning laws in the neighborhood and avoid intervening in this process". Thus, the impotence of the liberal system to regulate resources and enforce planning laws in terrain where sectorial interests clash, lead to the outcome in this case.

Concluding discussion: appropriation of territory- failure of liberalism or all-you-can-grab in Planning?

This paper has examined the spatial encounter that is taking place between two interest groups struggling over space and resources in the Kiryat-Ha'Yovel neighbourhood in Jerusalem. The research has revealed the different strategies they have adopted to claim territory, distinguish their abilities and limitations to influence the neighborhoods' private and public space, as well as the limitations of the planning system.

In-depth door to door surveys indicated the way direct, effective collaborations of individuals of the Kol-Torah community and their leadership led to a gradual appropriation of Zangwill Street. Relying on existing community infrastructures of BayitVa'Gan made it possible to concentrate the community in a compact area at relatively low cost. This collaboration is surprising in light of the accounts about the limited group discipline of the Lithuanian Haredim, and can be largely explained by the attractiveness of Kiryat Ha'Yovel, which offers a solution to housing problems within the green line of Jerusalem. Including the young families in the community territory has increased the community's volume and the prestige of its leaders.

This behaviour, spreading to the large residential buildings on the peripheral streets of the neighborhood, demonstrated that the Haredim are effective strategists in planning, organising, and executing a homogeneous space that is characterised by its own laws. The 'Action Committee to Preserve the Character of Kiryat-Ha'Yovel' had two weaknesses in front of the Haredi group. First, they were not sufficiently sharp and effective. They resisted exclusion, but produced it by insisting on applying the term "mixed neighborhoods" exclusively to non-Haredi Jews. One may assume that the 'pluralistic populations' wouldn't wish to coexist also alongside Arab or African 
communities. Secondly, the interests of individuals contradicted the interests of the group, and therefore failed to produce compliance. In the urban reality, the inherent lack of collaboration and cohesion in the secular population limited their ability to safeguard their spatial rights and maintain their social practices. The spatial predominance of KolTorah increased, and the veteran residents have left the area.

The abilities and limitations of interest groups to claim territory should be combined with theories that underestimate the role of different levels of cooperation in operating segregation processes. Despite some resemblances, the organised entry into Zangwill Street differs from the classic invasion-succession model, according to which relatively free individuals move spontaneously into areas of higher-status populations, using private capital, and also from a racial blockbusting in US cities, which involved planned invasions even if the newcomers weren't the planners. In Zangwill Street, the group action was supported by community capital, organised collaboration and implementation. The gradient of prices on Zangwill Street shows a moderate drop in prices and after that a rise, in the wake of the formation of an internal market. When the veteran population left, there was a sharp decline in prices. Individual cooperation with the group's action is evident in the dramatic increase in housing prices after the "tie-break". In those cases the newcomers created spatial dominance. Kol-Torah dominance compelled Haredi groups that entered afterwards to adapt themselves to the patterns they have established. Since these areas reflect compromises that were made between the preference for segregation and urban constraints, they tended to be more heterogeneous than the Israeli-Lithuanians enclaves.

Similar to the shift of ethno-religious boundaries in Indian cities, direct collaboration of individuals with their leadership has gradually inserted the cultural language of Kol-Torah into Zangwill Street, and re-shaped the boundary between acceptable and unacceptable uses. This has involved property lines, religious composition as well as acts of symbolic and everyday violence. Unlike the Indian case, the apartment prices in the Haredi enclaves are significantly higher than similar apartments in the area, which has drawn the boundaries between identities and provided a particular utility to the larger mission of the haredification of Kiryat-Ha'Yovel.

This study contributes two new ideas to the knowledge base of spatial behavior of the Haredi population in Israel. The first is the detailed resolution of the process of expansion of the Haredi enclave, and the second is 'terrain of interests'; an idea describing social/interests groups competing over space and resources using planning 
methods and discourse of citizen rights. The Haredim do not bargain but augment their potential influence on decision-making. When official allocations are inadequate, the group turns into unofficial modes of action to achieve sectorial goals. Conversely, secular residents regard themselves as autonomous homeowners. They expect the authorities to support their views and demand the policy makers defend what they see as their rights and stop sectarian allocation of public resources. The secular residents may not be good at organising themselves or prepared to sacrifice individual interests, but the rules of the game have been blurred and seem to be rigged against them.

While the Kiryat-Ha'Yovel study suggests that appropriation of territory can be considered as a failure of liberalism that couldn't balance public rights according to its fundamental agenda, conclusion is equivocal. After all, could planning intervention actually change the outcome, enacted in various places on the world stage? And if not will Jerusalem become a network of self-created ghettos within a diminishing pluralist population? This process can also be seen as a bottom-up reaction to the changing role of the state and public policies in developing cities. In an absence of a shared civil society, increasing involvement of interest groups trying to catch some of the power of national governments, undermining the institutionalised logic of economics, identities, governance and cultural norms. The limited ability of the planning system to protect the public interest and guarantee its rights dissolute, causing the system to betray the values on which it is based.

To conclude, the dynamic of residential competition could be relevant to many other situations, such as separatists Catalans, Scots, Indian states or US cities, where differences in lifestyle characterisations may lead to a collision between interest groups. Understanding that this is not a local struggle, but part of national ideologies, and formulating common rules between communities to engage one another while using planning tools, may balance competing interests. Further research may reveal the degree to which this is a typical process.

Alexander, E. R., (2002). The public interest in planning: from legitimation to substantive planevaluation. Planning Theory, 1, $226-249$

Alfasi, N., (2014). Doomed to informality: Familial versus modern planning in Arab towns in Israel, Planning Theory \& Practice 4 (3) 170-186

Almond, G., Appleby, S., \& Sivan, E. (1995). Fundamentalism: genus and species, In M. Marty \& S. Appleby (Eds.) Fundamentalisms Comprehended (399-424). Chicago: University of Chicago Press. 
Alterman, R and Gavrieli, E., (2008) Betwwen extreme centralization and hesitant decentralization, The centre for urban studies, The Technion, Haifa

Altvater, E. (1998). Theoretical Deliberations on Time and Space in Post-socialist Transformation. Regional Studies 32 (7) 591-605

Ammerman, Nancy Tatom. (1987). Bible Believers, Fundamentalism in the Modern World. University of Rutgers Press, London.

Anderson, L., \& O'Dowd, J. (1999). Borders, Border Regions and Territoriality: Contradictory Meanings, Changing Significance. Regional Studies, 33 (7), 593-604.

Aran, G., Stadler, N., \& Ben-Ari, E. (2008). Fundamentalism and the masculine body: The case of Jewish Ultra-Orthodox men in Israel. Religion, (March), 38 (1) 25-53

Bankston, C.L.III., \& Zhou M. (1995). Religious Participation, Ethnic Identification, and Adaptation of Vietnamese Adolescents in an Immigrant Community. The Sociological Quarterly, 36 (3) 523 534

"Behadrey Haredim", the Haredim news website on May 18, 2005, (http://www.bhol.co.il/).

Katz,Y. Rabbi Elyashiv responds to married yeshiva students: "Don't give in, even if you break the law", by Hadrei Haredi website 04/04/2009 http://ladaat.net/forum/index.php?topic=34011.msg402751\#msg402751

Berman, E., \& Klinov, R. (1997). Human Capital Investment and Nonparticipation: Evidence from sample with infinite horizons (or Jewish Father Stops Going to Work). Discussion Paper Series No. 97.05, Jerusalem: The Maurice Falk Institute for Economic Research in Israel

Blumer, H. (1951), Collective Behavior, In: A. M. Lee (ed.) New Outline of the Principles of Sociology, New York: Barnes and Noble 166-222.

Boal, F. W. (2008). Territoriality on the Shankill-Falls Divide, Belfast. Irish Geography 41( 3), 349366

Bollens, Scott., On Narrow Ground: Urban Policy and Ethnic Conflict in Jerusalem and Belfast, State University of New York Press, 2000

Campbell, H. (2002). Planning: an idea of value (Inaugural Lecture) Town Planning Review, 73(3), pp.271-288

Castells, M. (1997). The Power of Identity. The Information Age: Economy, Society and Culture (Vol. II.) Cambridge, MA; Oxford, UK: Blackwell.

Davies A R, 2001, “Hidden or hiding? Public perceptions of participation in the planning system" Town Planning Review 72193^216

Dean, H. (2011). Welfare, identity and the life course. In: Baldock, John and Mitton, Lavinia and Manning, Nick and Vickerstaff, Sarah, (eds.) Social policy. Oxford University Press, Oxford, UK, pp. 201-244. ISBN 9780199570843

Denzau T. \& M. Munger. (1986). Legislators and interest groups: how unorganized interests get represented. The American Political Science Review. 80(1)89-106.

Desai, Renu (2011). Producing and Contesting the "Communalized City": Hindutva Politics and Urban Space in Ahmedabad, In N. AlSayyad and M. Massoumi (eds.) The Fundamentalist City? Religiosity and the remaking of Urban Space, Routledge, NY 
Drezon-Tepler, M. (1990). Interest groups and political change in Israel ,NY: State University of New York press.

Feitelson, E. (2011). Issue generating assessment: bridging the gap between evaluation theory and practice? Planning Theory \& Practice, 12 (4) 549-568

Fischer, C. S. (1982). To dwell among friends: personal networks in town and city. Chicago: University of Chicago Press.

Shilhav, Y. \& Friedman, M. (1985). Growth and Segregation: The Haredi Community of Jerusalem. The Jerusalem institute for Israel Studies, Jerusalem (in Hebrew).

Friedman, M. (1991). The Haredi Ultra-Orthodox Society: Sources Trends and Processes. Jerusalem: The Jerusalem Institute for Israel Studies (Hebrew).

Funk C. (2000). The dual influence of self-interest and societal interest in public opinion. Political Research Quarterly, 53(1)37-62.

Giddens, A. (1984) The Constitution of Society: Outline of the Theory of Structuration, Cambridge: Polity.

Gonen, A. (2006). Between Torah Learning and Wage Earning. The London Experience and Lessons for Israel. Jerusalem: The Floersheimer Institute for Policy Studies (in Hebrew).

Gottman, J. (1973) The Significance of Territory, University of Virginia Press: Charlottesville

Granovetter, M. (1978). Threshold Models of Collective Behavior. The American Journal of Sociology, 83 (6) 1420-1443 State

Hasson, S. (1996). The Cultural Struggle Over Jerusalem: Accommodations, Scenarios and Lessons. Jerusalem: The Floersheimer Institute for Policy Studies (in Hebrew).

Hawley, A. H.(1950). Human Ecology: A Theory of Community Structure. New York: Ronald Press.

Healey, P. (1997). Collaborative Planning: Shaping Places in Fragmented Societies. London: Macmillan.

lannaccone LR. 1992. Sacrifice and stigma: reducing free-riding in cults, communes, and other collectivities. J. Polit. Econ. 100: 271-91

Ignatieff, Michael, 1993a, Blood and Belonging (New York: Farrar, Straus and Giroux).

Kolossov, V. 2005: Border studies: changing perspectives and theoretical approaches. Geopolitics 10 (3) 606-632

Malkin, Y. (2005). Secular Judaism: Faith, values, and spirituality. London: Valentine Mitchell.

Malmberg, M. (1980). Human Territoriality: Survey of Behavioural Territories in Man with Preliminary Analysis and Discussion of Meaning, Mouton Publishers.

Mehlhorn, D (December 1998). "A Requiem for Blockbusting: Law, Economics, and Race-Based Real Estate Speculation". Fordham Law Review 67: 1145-1161.

Miller D. (1999). The norm of self-interest. American Psychologist, 54(12)1053-1060.

Nahum-Halevi, R. (25.06.2009) Kiryat-Ha'Yovel, summer 2009: Religious wars merge with wars over real estate prices. Haaretz: The Marker. (Hebrew).

Newman, D. (2003) On borders and power: a theoretical framework. Journal of Borderland Studies 18, 13-24. 
Park, R. E. (1936). Succession, an Ecological Concept, American Sociological Review (1) 171179.

Paasi, A. 1996: Territories, boundaries and consciousness. New York: Wiley .

Sack, R D. (1983) Human Territoriality: A Theory, Annals of the Association of American Geographers (73) 1 55-74

Saegert, S., \& Winkel, G. H. (1990). Environment psychology, Annual Review of Psychology, (41) 441-477.

Sharkansky, I. (1996). Govercivilning Jerusalem. Detroit: Wayne State University Press.

Shilhav, Y. (1993). The Emergence of Ultra-Orthodox Neighborhoods. In E. Ben-Zadok (ed.), Local Communities and the Israeli Polity (pp. 157-187). Albany: SUNY Press.

Shilhav, Y. (1998). Ultra-Orthodoxy in Urban Governance in Israel. Jerusalem: The Floersheimer institute for policy studies.

Shiloh, E. (January 5, 2009). Barkat canceled the allocation of a lot in Kiryat-Ha'Yovel to the ultraOrthodox. Arutz 7 Radio,. http://www.inn.co.il/News/News.aspx/183750

Sprinzak E, (1986). What was Right in His Own Eyes: Illegalism in Israel Society in Hebrew .Poalim: Library, Tel Aviv

Stone, C., \& Salisbury R. (1969). An exchange theory of interest groups. Midwest Journal of Political Science, 13(1)1-32.

Taylor, N. (1998). Urban Planning Theory Since 1945. London U.K: Sage Publications.

Tajfel, H., \& Turner, J. C. (1986). The social identity theory of intergroup behaviour. In S. Worchel \& W. G. Austin (Eds.), Psychology of intergroup relations (2nd ed., pp. 7-24). Chicago: NelsonHall.

Valins, O. (2003). Stubborn identities and the construction of socio-spatial boundaries: ultraorthodox Jews living in contemporary Britain. Transactions of the Institute of British Geographers 28 (2), 158-175.

Waterman, S. and Kosmin, B. (1988). Residential patterns and processes: a study of Jews in three London boroughs. Transactions of the Institute of British Geographers 13, 79-95.

Wirth, L. (1956). Community Life and Social Policy. University of Chicago Press: Chicago.

Yiftachel, O. (2006). Ethnocracy: Land and Identity Politics in Israel/Palestine. University of Pennsylvania Press: Philadelphia. 


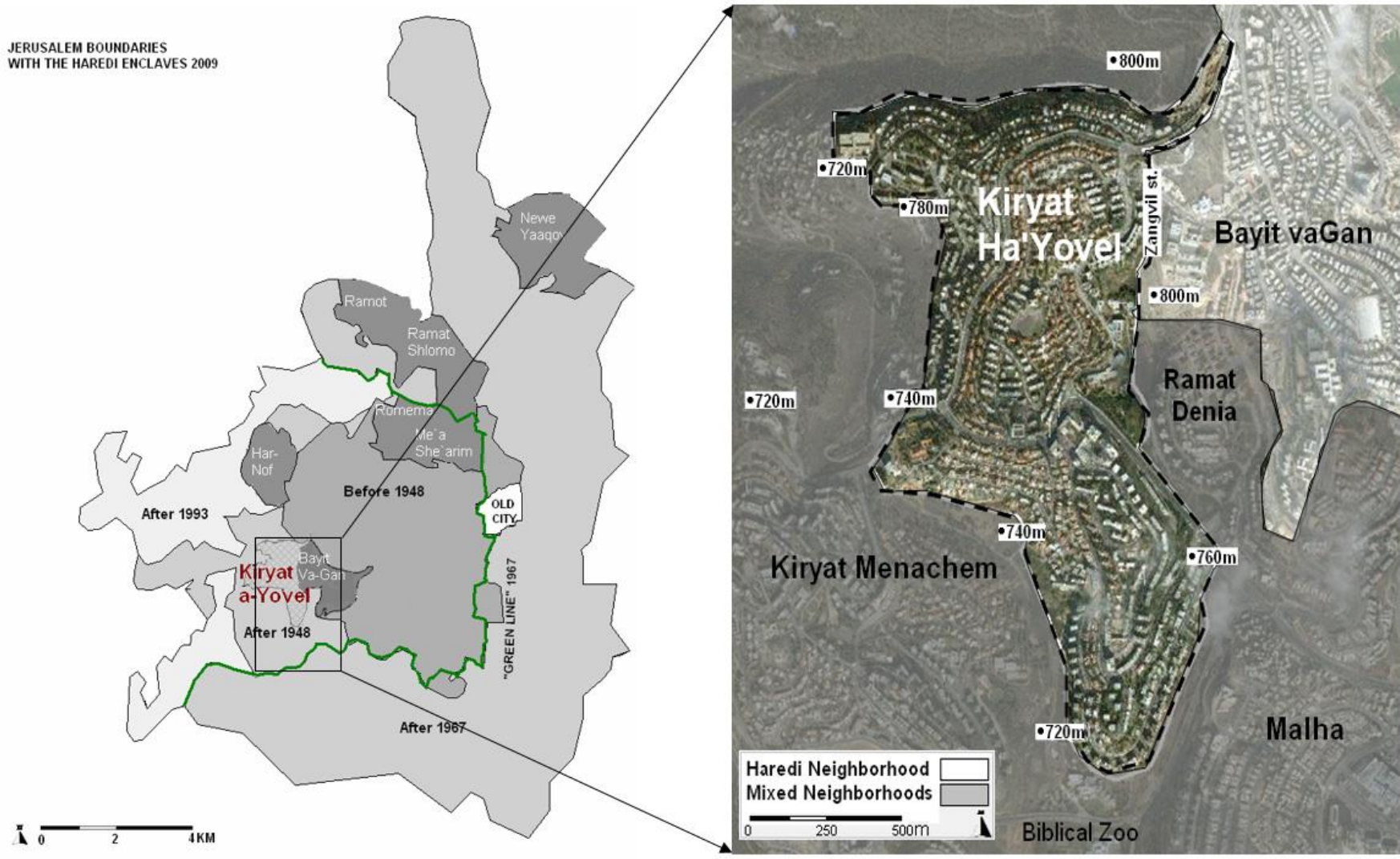

Fig. 1: Map of Jerusalem with the Haredim enclaves. (a) Kiryat-Ha'Yovel marked. (b) KiryatHa'Yovel and the adjacent neighborhoods 


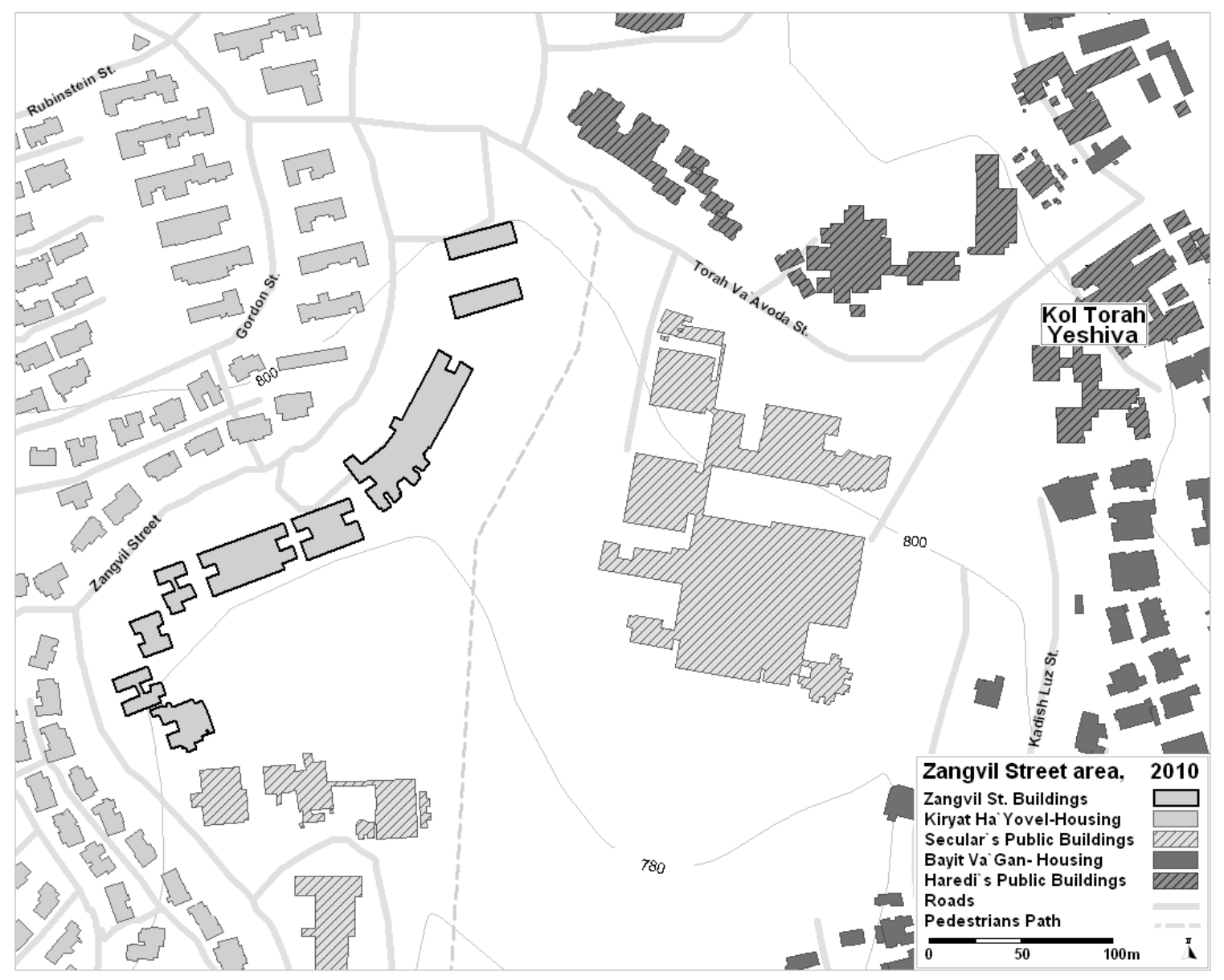

Fig. 2: Map of Zangwill Street area 


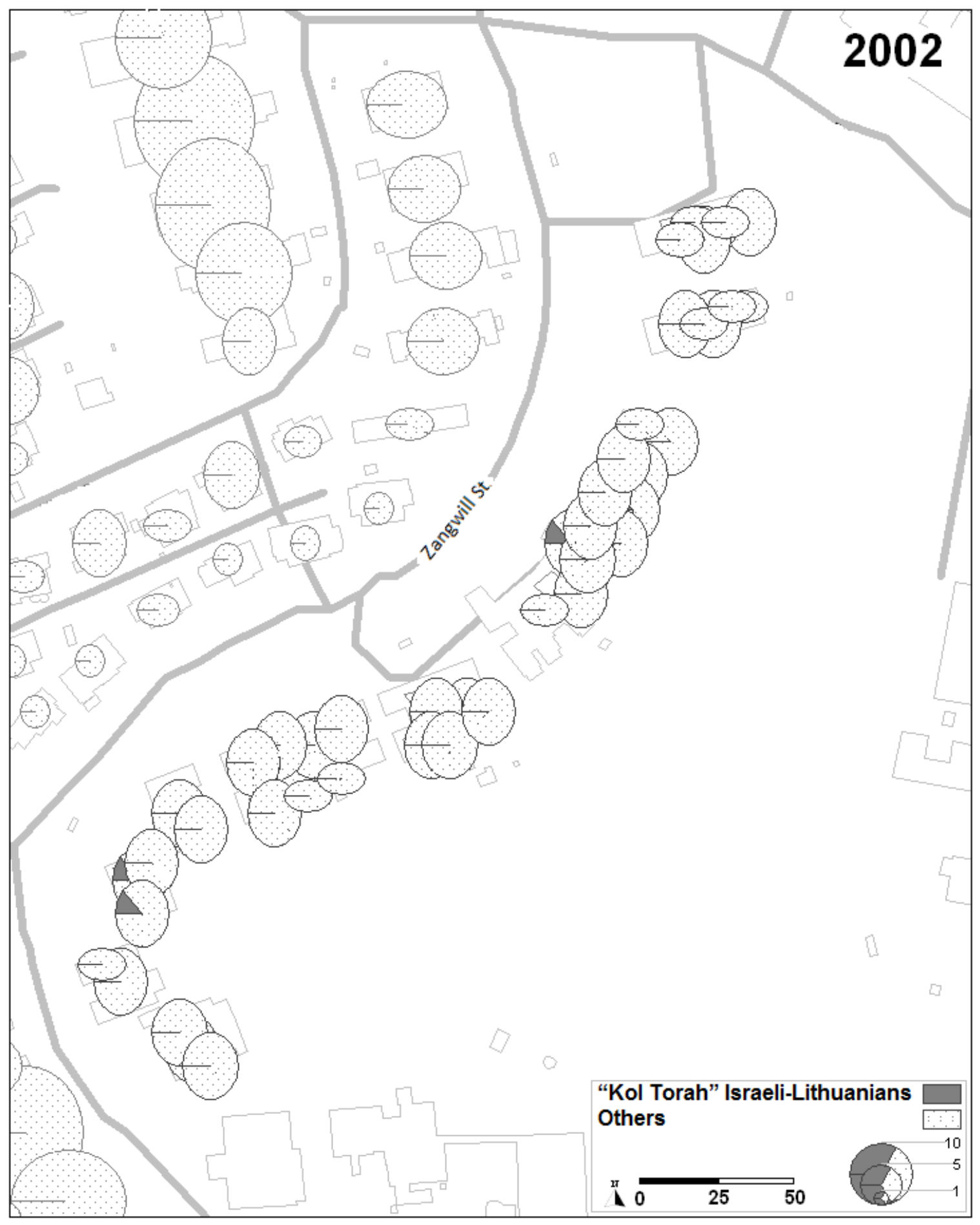




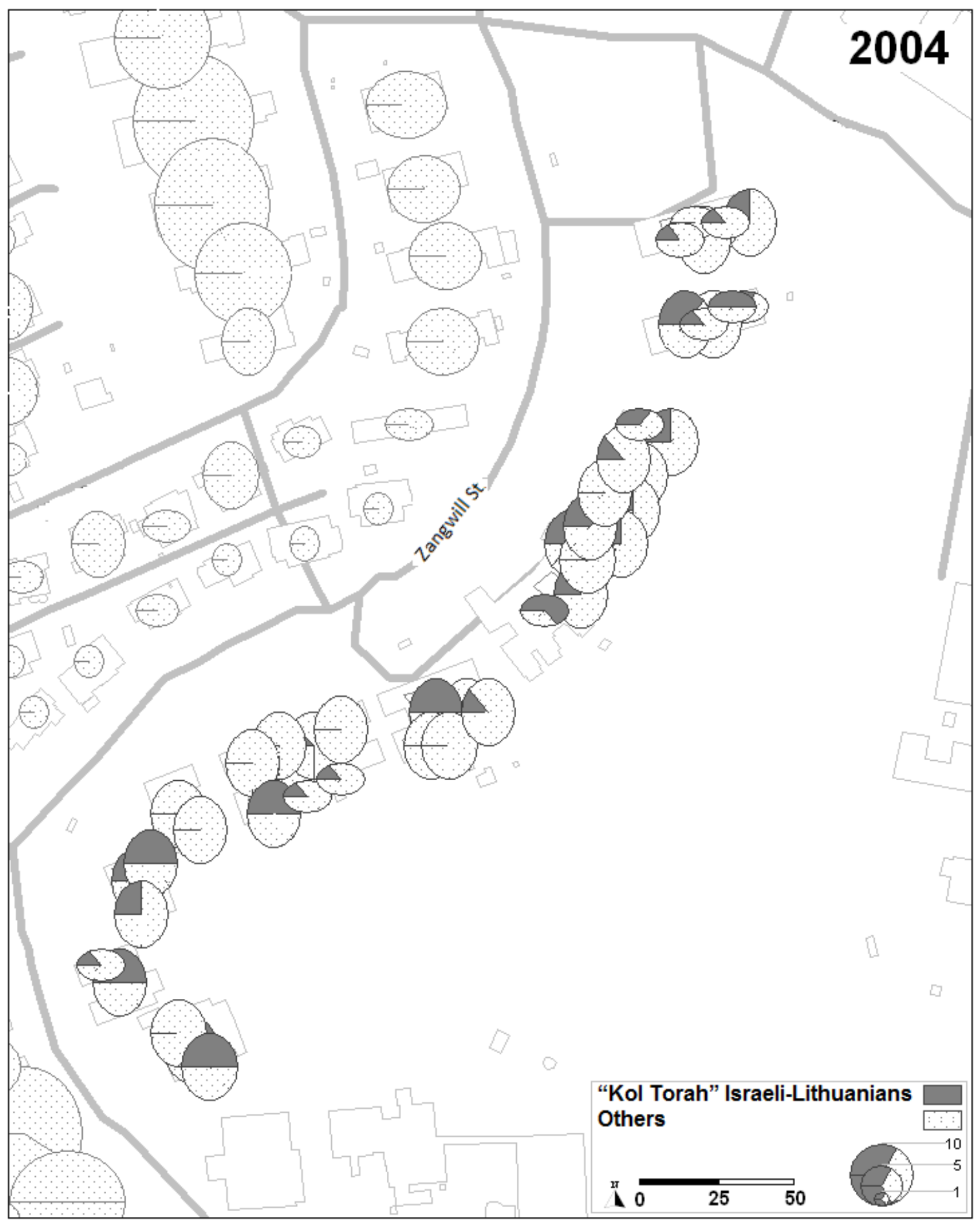




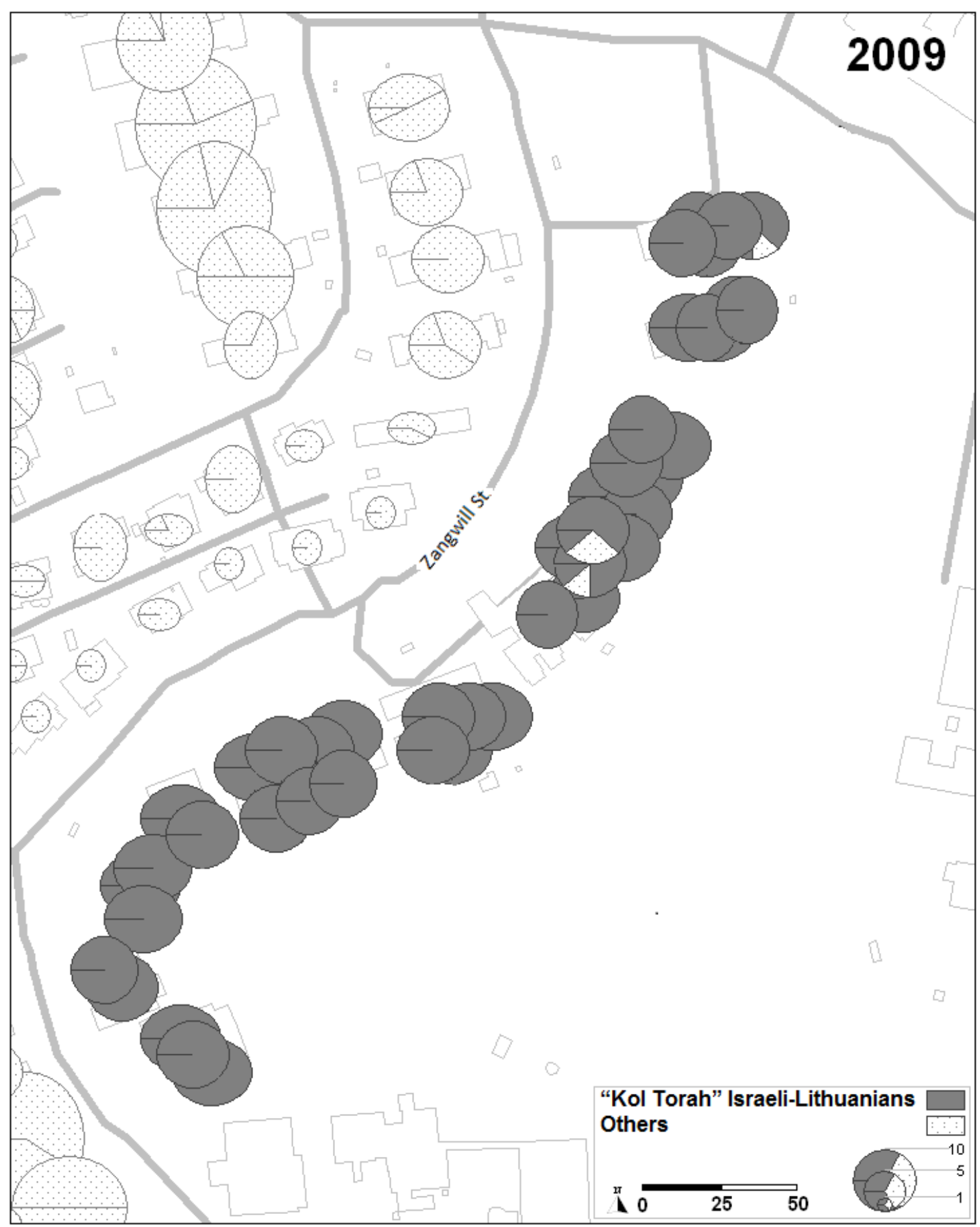

Fig. 3a-c: Spatial intervention of Kol-Torah to Zangwill Street 2002, 2004 and 2009 


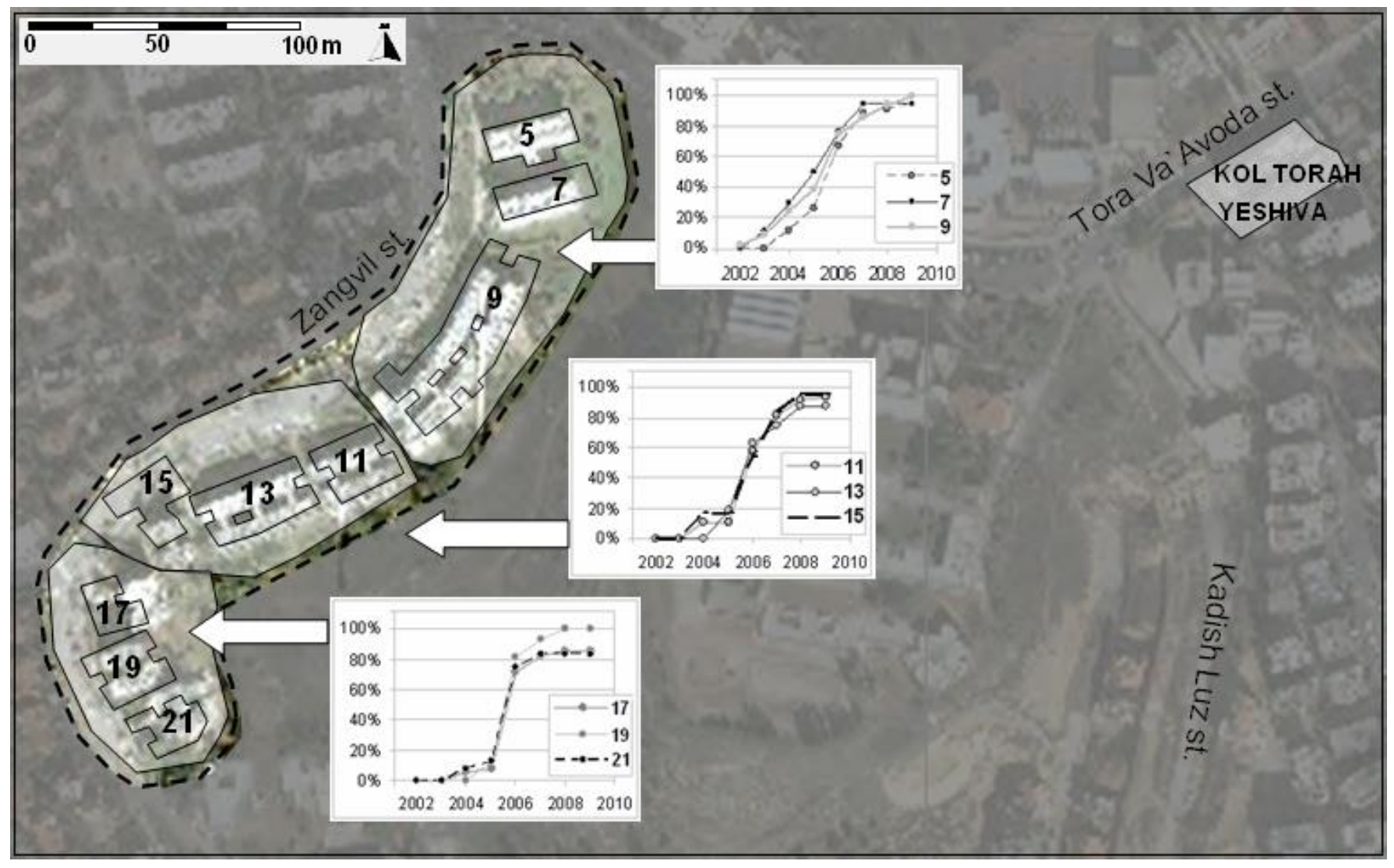

Fig. 4: Entry of Kol-Torah residents into apartments on Zangwill St., by year 


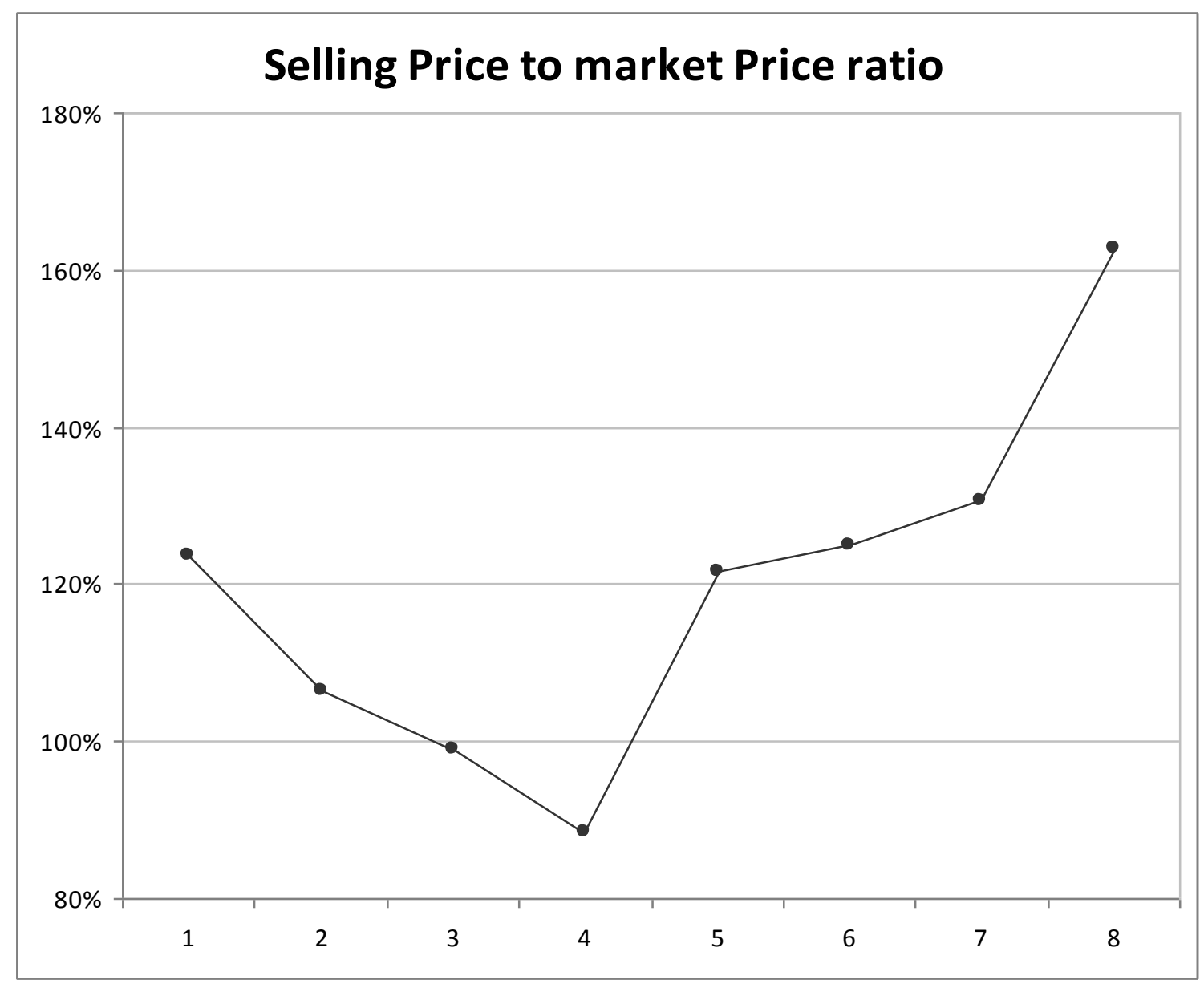

Fig. 5: Average selling price to market price ratio as dependent on the sequential number of apartment among those sold by the veteran to Israeli-Lithuanians, for each section. 


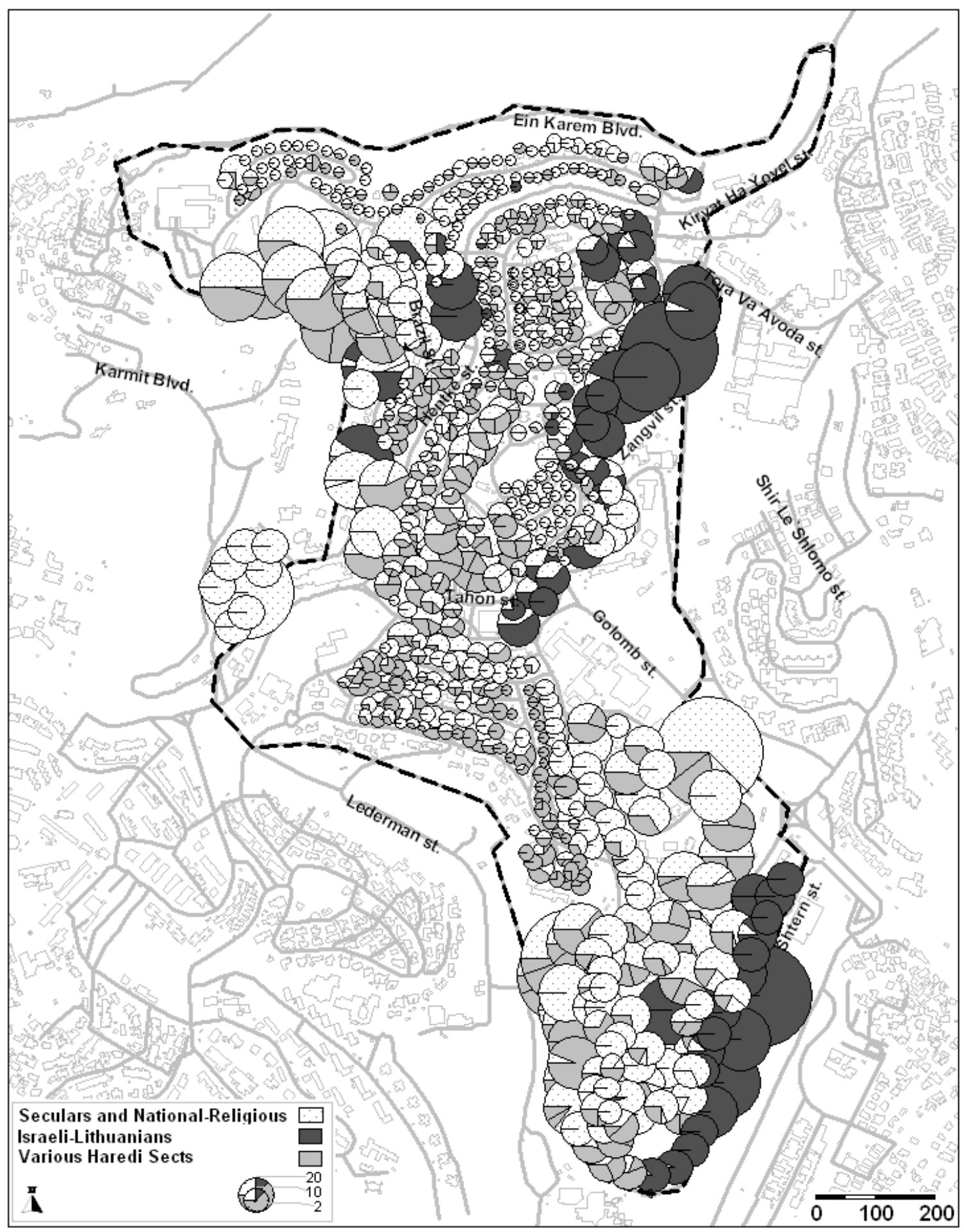

Fig. 6: Distribution of population in Kiryat Ha'Yovel, 2009. 
